\title{
Abordagens de questões sociorraciais na rede pública de ensino.
}

Leidiane Martins Ribeiro'; Alana Caroline Monteiro da Silva ${ }^{2}$; Jéssica Dias da Silva ${ }^{2}$; Ruth de Fátima Sousa ${ }^{2}$; Paulo Alexandre de Castro ${ }^{3}$; Leonardo Santos Andrade ${ }^{3}$; Geraldo Sadoyama $^{3}$; Adriana S.P.Sadoyama ${ }^{3}$.

\section{Resumo}

A consciência negra faz-se refletir sobre a inclusão do negro na sociedade brasileira e sobre suas lutas e conquistas realizadas ao longo dos anos, a discussão racial vem se fazendo bastante presente na sociedade. É preciso combater o preconceito, desde a tenra idade e lutar pelo respeito e valorização da diversidade. A finalidade desse trabalho é de proporcionar aos alunos uma reflexão sobre a importância do tema racismo em sala, analisar sua influência no convívio social e salientar a importância do dia da consciência negra. Por esse motivo, foi abordado o tema com os alunos da escola parceira do programa institucional de bolsa de iniciação a docência PIBID, no intuito de conscientizá-los sobre a igualdade racial, pois se entende que eles construirão o senso critico sobre o assunto nas gerações futura. A primeira aula foi teórica, e para a introdução do tema, foram utilizados recursos audiovisuais para melhor entendimento das crianças, primeiro foi apresentado a eles a trajetória dos povos africanos, em seguida foi apresentado à cultura e religião africana e como influenciou na construção da cultura Brasileira, a segunda aula foi destinada as atividades praticas e artísticas, os alunos confeccionaram mascaras e berimbaus. A participação deles nas oficinas foi bastante proveitosa, pois participaram sempre questionando o porquê das atividades e

${ }^{1}$ Professora supervisora do programa PIBID interdisciplinar CAPES, Leidiane Martins Ribeiro,

${ }^{2}$ Aluna de licenciatura em letras português: Alana Caroline Monteiro da Silva; licencianda em biologia: Jéssica Dias da Silva; licencianda em pedagogia: Ruth de Fátima Sousa; UFGCAC (Universidade Federal de Goiás), leidianemartinsribeiro@gmail.com ${ }^{1}$, alanaacarolinemonteiro@gmail.com²,Jeehdias1991@gmail.com², ruth_fátima1461@hot mail.com².

${ }^{3}$ Coordenadores de Área do Subprojeto Interdisciplinar - (PIBID, UFG/RC), E-mail: gsadoyama@yahoo.com.br; drisadoyama@gmail.com; padecastro@ufg.br; 1s_andrade@yahoo.com.br 
sempre buscando o conhecimento sobre o assunto abordado. Com a confecção de mascaras e berimbaus, pode-se perceber que os alunos entenderam o significado do dia da consciência negra e a importância que esses objetos fabricados possuem na cultura africana. Esse dia 20 de novembro não passará mais em branco para eles, pois com todo o conteúdo apresentado estimulouos a repensar sobre suas atitudes como cidadãos e que as dores e as conquistas do povo negro devem ser celebradas nesse dia. Resultado bastante positivo, pois se conseguiu a participação de todos nas oficinas. Conclui-se que, estratégias simples podem ter efeitos positivos para reforçar a importância da consciência negra para os alunos da rede municipal de ensino.

Apoio: PIBID/CAPES

Palavras Chave: consciência negra; racismo; ensino 